\title{
The COVID-19 pandemic and sovereign credit risk
}

\author{
Wei-Fong Pan \\ University of Reading, Reading, UK \\ Xinjie Wang \\ Southern University of Science and Technology, Shenzhen, China \\ $\mathrm{Ge} \mathrm{Wu}$ \\ University of Richmond, Richmond, Virginia, USA, and \\ Weike Xu \\ Clemson University, Clemson, South Carolina, USA
}

\begin{abstract}
Purpose - The purpose of this study is to examine the effects of the coronavirus disease 2019 (COVID-19) pandemic on sovereign credit default swap (CDS) spreads using a large sample of countries.

Design/methodology/approach - In this paper, the authors use a wide set of the sovereign CDS data of 78 countries. To measure the magnitude of the COVID-19 pandemic, the authors use the daily change of confirmed cases collected from Our World in Data. They use panel regressions to estimate the impact of the COVID-19 pandemic on sovereign credit risk.

Findings - The authors show how sovereign CDS spreads have widened significantly in response to the COVID-19 pandemic. Based on the most conservative estimate, a 1\% increase in COVID-19 infections leads to a $0.17 \%$ increase in sovereign CDS spreads. Furthermore, this effect is stronger for developing countries and countries with worse healthcare systems. Government policies partially offset the impact of the COVID-19 pandemic, although these same policies also lead to widening sovereign CDS spreads. Sovereign CDS spreads narrow dramatically several months after the outbreak of the COVID-19 pandemic. Overall, the results suggest that the ongoing COVID-19 pandemic has been a massive shock to the global financial stability.

Originality/value - This paper provides new evidence that COVID-19 widens sovereign CDS spreads. The authors further show that this widening effect is felt most strongly in developing economies.
\end{abstract}

Keywords Crisis, Economic uncertainty, COVID-19, Pandemic, Sovereign CDS spread

Paper type Research paper

\section{Introduction}

At the time of writing, the coronavirus disease 2019 (COVID-19) outbreak has spread across the world and has led to more than one million deaths and 33 million confirmed cases between 2019 and 2020 [1]. The pandemic has led to renewed interest in infectious disease surveillance and control, as well as in the economic impact of such diseases. The US real gross domestic product (GDP) plunged by a record of $32.9 \%$ in the second quarter of 2020 . As a result, several governments and institutions have attempted to estimate the economic impact of COVID-19. For instance, The Economist has revised its growth forecasts for all countries and is now predicting that the global economy will experience a $2.2 \%$ contraction in 2020 and that most G20 nations are likely to enter a recession due to the pandemic [2]. In a recent Brookings Institute report, McKibbin and Fernando (2020) also suggest that the global economy will contract in 2020 . They state that the resulting economic costs could be mitigated by greater investment in public health systems across economies, especially in less developed countries.

There is a fast-growing body of literature on the impact of COVID-19 on the economy and financial markets [3]. For example, Baker et al. (2020) develop new measures for gauging the

Xinjie Wang acknowledges financial support from Southern University of Science and Technology (Grant No. Y01246110) and the Department of Education of Guangdong Province (Grant No. 2020KZDZX1189).

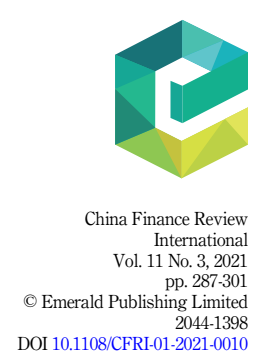


CFRI 11,3

\section{8}

risk from COVID-19 and demonstrate that this pandemic has had a strong impact on the stock market. Mazur et al. (2020) document how COVID-19 triggered the US stock market crash in March 2020. Njindan Iyke (2020) finds that COVID-19 can serve as a predictor of returns and of the volatility of foreign exchange markets. Adekoya and Oliyide (2020) find that COVID-19 drives connectedness among commodity and financial markets.

Closely related are several recent studies focusing on the effects of the COVID-19 pandemic on credit risk. Agca et al. (2020) show that the credit default swap (CDS) spreads of US firms with supply chain partners in China increased when this supply chain link was disrupted following the imposition of lockdown restrictions. Kartal (2020) finds an increase in the CDS spreads of Turkish firms during the COVID-19 pandemic. Kwan and Mertens (2020) estimate the effects of COVID-19 on firms' CDS spreads. They show that there has been a widening of CDS spreads in all sectors. Among investment-grade firms, those in the energy sector have experienced the greatest widening. Daehler et al. (2020) adopt a two-stage econometric approach to explain the evolution of emerging market (EM) sovereign CDS spreads in the first half of 2020. They find that EMCDS spreads are not driven by COVID specific risk factors but rather by traditional determinants such as fiscal space, oil shocks and monetary policies.

This paper also focuses on the effects of COVID-19 on credit risk. In doing so, we examine the changes in sovereign CDS spreads that have occurred during the COVID-19 pandemic. In general, sovereign CDS spreads reflect investors' expectations toward sovereign default risk. If investors perceive higher default possibility of sovereign debts, they are willing to pay a higher premium to hedge against (or speculate on) the risk, driving the CDS spreads to higher levels. As shown during the European debt crisis, the volatile price movements of sovereign CDS spreads can rattle the financial stability of an entire country.

The effects of COVID-19 on sovereign CDS spreads are felt in two different ways: increased sovereign default risk (expected default losses) and increased risk premiums (Pan and Singleton, 2008; Longstaff et al., 2011). First, despite falling tax revenues, many countries have implemented costly fiscal stimulus plans to overcome the pandemic [4]. These actions substantially raise global debts, thereby increasing the default risk of these sovereign debts. Furthermore, many countries have adopted stringent policy responses, such as lockdowns and social distancing. These policies directly decrease firm revenues and household incomes. As a result, the heightened risk from COVID-19 can also be seen to have the effect of increasing expected default losses. Second, during the COVID-19 pandemic, which increases the level of uncertainty, risk-averse investors require excess returns to hold risky assets. Pouzo and Presno (2016) have developed a general equilibrium model of sovereign debt and show that investors require higher returns on sovereign bonds for bearing default risk in an environment of higher uncertainty. Gilchrist and Zakrajsek (2012) decompose bond credit spreads into risk premium and the probability of default and find that the risk premium part is related to economic conditions. Therefore, we should observe a higher risk premium in sovereign CDS spreads in reaction to the current pandemic.

Compared to previous studies that have addressed this issue, we use a wider set of the sovereign CDS data (78 developed and developing countries) to test the effects of COVID-19 on credit risk. To measure the severity of the COVID-19 pandemic, we use the natural logarithm of the number of daily new COVID-19 cases per million capita from Our World in Data, an organization which tracks global coronavirus-related data. We find that sovereign CDS spreads are significantly positively associated with the COVID-19 pandemic. Based on the most conservative estimation, a 1\% increase in COVID-19 infections leads to a $0.17 \%$ increase in sovereign CDS spreads. This positive relationship is robust after controlling for US excess stock returns, treasury yields, corporate yield spreads, equity premiums, VIX index, US term spreads, regional sovereign CDS spreads, global sovereign CDS spreads, time fixed effects and country fixed effects. We also find that the effect of the pandemic on sovereign CDS spreads peaks in March/April and then fades sharply after May. For example, 
the sovereign CDS spread of European countries, which reaches a peak of around $120 \mathrm{bps}$ in March, declines to $80 \mathrm{bps}$ in June. The sovereign CDS spread of China peaks at around $90 \mathrm{bps}$ in March and then drops to about 50 bps in May.

It is reasonable to expect that the impact of the pandemic on sovereign CDS spreads might vary across different economies. Intuitively, countries with worse healthcare systems might be expected to be more vulnerable to the COVID-19 pandemic. Consequently, the effect of the pandemic on sovereign CDS spreads should be more pronounced for countries with worse healthcare systems. Additionally, compared with developed economies, EMs have greater risk associated with their sovereign bonds. As a result, the effect of the COVID-19 pandemic on CDS spreads could be stronger in developing countries than that in developed countries. Our cross-sectional analyses lend support to these two conjectures.

We conduct several robustness checks. First, we show that our results remain the same after using several different clustering methods. Second, the effect of the pandemic on sovereign CDS spreads is also robust after using an alternative proxy for the severity of the pandemic. Finally, our results also remain robust after excluding the United States, Brazil and India, which are the top three countries with the greatest number of confirmed cases.

The contributions of this study are twofold. First, we contribute to the growing literature regarding the effects of COVID-19 on financial markets (e.g. Agca et al., 2020; Baker et al., 2020; Daehler et al., 2020; Falato et al., 2020; Goodell, 2020; Kartal, 2020; Kwan and Mertens, 2020; Reinders et al., 2020). In particular, our study provides new evidence that COVID-19 widens sovereign CDS spreads. We further show that this widening effect is felt most strongly in developing economies. Second, our paper contributes to the literature on the determinants of sovereign CDS spreads. Previous studies have shown that the determinants of sovereign CDS spreads can be divided into local and global factors (Berg and Sachs, 1988; Grossman and Huyck, 1988; Bulow and Rogoff, 1989; Yu, 2002; Duffie et al., 2003; Remolona et al., 2008; Gerlach et al., 2010; Longstaff et al., 2011; Gündüz and Kaya, 2014; Galariotis et al., 2016; Wang et al., 2019). Our study adds to this strand of literature by showing that the COVID-19 pandemic is also an important driving factor of sovereign CDS spreads.

The remainder of this study proceeds as follows. Section 2 describes the data and the methodology used in this study. The empirical results are reported in Section 3. Section 4 concludes this study.

\section{Data and methodology}

In this section, we discuss our data, the main variables, the summary statistics and the methodology employed.

\subsection{Data and summary statistics}

Our data are collected from three main sources. Our sovereign CDS contracts data are from Markit Group Limited for the period from January 2, 2020 to August 31, 2020. Following Blanco, et al. (2005), Longstaff et al. (2005) and Longstaff et al. (2011), we focus on contracts with five-year maturity in our baseline regressions since they are the most liquid contracts. We require that each country has more than 10 observations in our sample period.

To measure the magnitude of the COVID-19 pandemic, we use the daily change of confirmed cases collected from Our World in Data. Our World in Data collects coronavirusrelated data from Johns Hopkins University Coronavirus Resource Center. It also collects each country's healthcare infrastructure and economic development indicators. The control variables are mainly collected from Fred St Louis database.

Since we combine data from several sources, the sample period stretches from January 2, 2020 to September 11, 2020. The final sample consists of 10,718 observations in 78 countries. The list of the 78 countries is provided in Table A1. The details of variable definitions and data sources are reported in Table A2. 
CFRI 11,3

290
Table 1 reports the summary statistics of our variables. The CDS spreads are measured in basis points (bps). On average, a country in our sample has a sovereign CDS spread of 381 bps. The average daily change of confirmed cases per million capita is around 33. The standard deviations of both variables are obviously larger than the mean values, implying substantial variations in both sovereign CDS spreads and COVID-19 cases across countries.

Figure 1 plots sovereign CDS spreads and daily changes in COVID-19 cases averaged across countries. We also classify our sample countries into five geographical areas: Africa,

Table 1.

Summary statistics

\begin{tabular}{lrrrrr}
\hline & Mean & Median & Maximum & Minimum & Std. Dev \\
\hline Spread (bps) & 381.378 & 84.158 & 33043.940 & 4.634 & 1621.993 \\
Daily change of COVID-19 cases per million population & 33.204 & 4.170 & 1918.044 & 0 & 87.314 \\
U.S. stock returns (\%) & 0.065 & 0.270 & 9.340 & -12.000 & 2.508 \\
Treasury yields (\%) & 0.610 & 0.360 & 1.670 & 0.190 & 0.475 \\
Credit spread (\%) & 1.184 & 1.140 & 1.990 & 0.790 & 0.306 \\
Equity premium & -0.005 & 0.055 & 1.588 & -2.246 & 0.507 \\
VIX (\%) & 30.831 & 27.990 & 82.690 & 12.100 & 14.255 \\
Term spread (\%) & 0.440 & 0.510 & 1.160 & -0.200 & 0.237 \\
Regional CDS spread (bps) & 388.297 & 161.800 & 2640.903 & 44.672 & 507.704 \\
Global CDS spread (bps) & 381.138 & 301.557 & 803.305 & 228.498 & 168.304
\end{tabular}

Note(s): This table reports summary statistics of our key variables. Variable definitions are provided in Table A2. The sample period is from January 2, 2020 to September 11, 2020
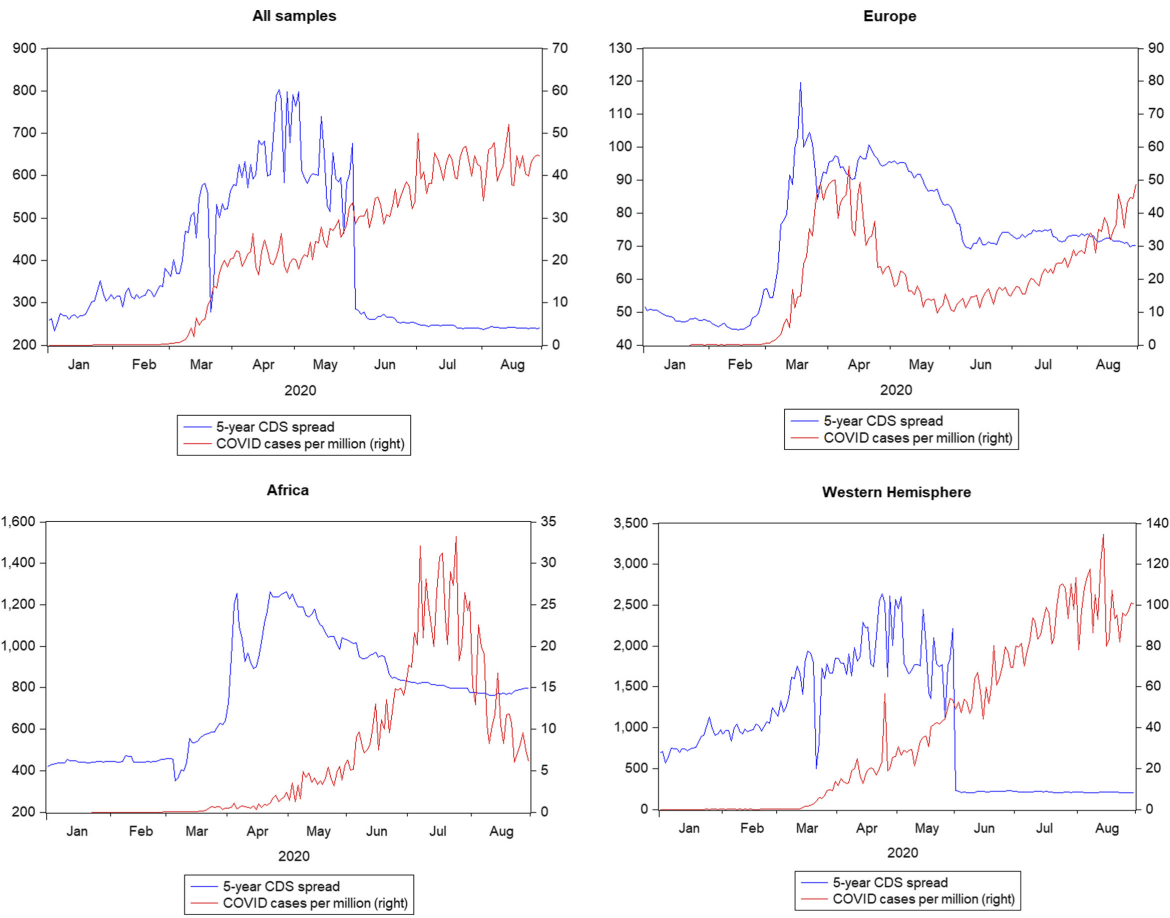

Sovereign CDS spreads and new COVID-19 cases across geographical areas

Note(s): This figure shows average sovereign CDS spreads (blue line, left axis, in bps) and new COVID-19 cases per million people (red line, right axis) across geographical areas 

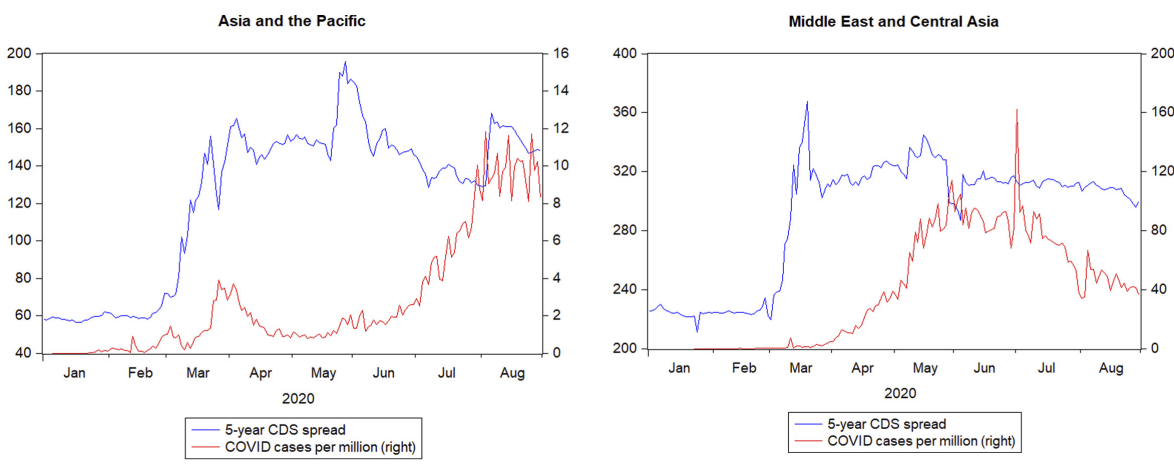

Sovereign credit risk
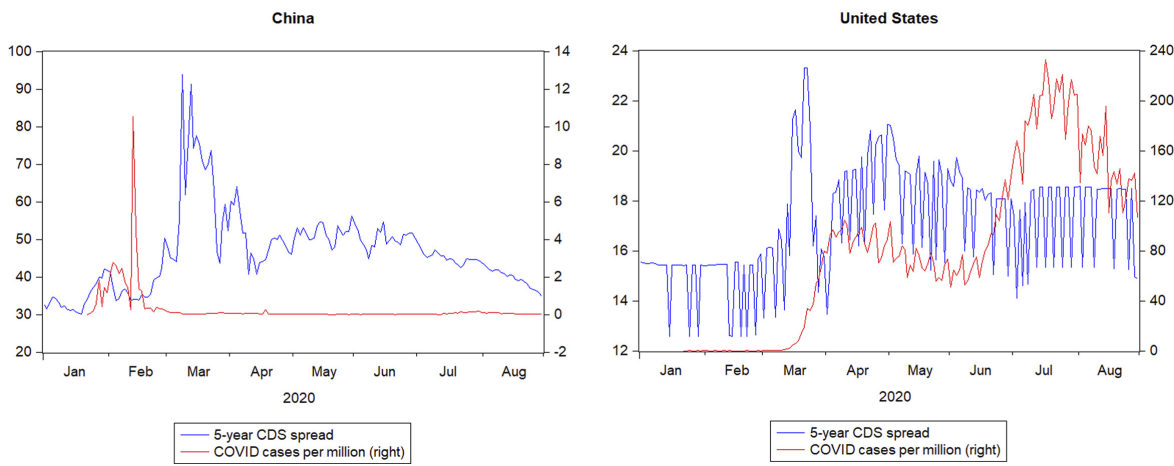

291

Asia and the Pacific, Europe, the Middle East and Central Asia, and the Western Hemisphere. Sovereign CDS spreads increase significantly in March 2020 and peak in April 2020. This period corresponds to the initial outbreak of the COVID-19 pandemic. There is a noticeable positive relationship between COVID-19 new cases and CDS spreads before the end of May 2020. Such positive correlation is concentrated in the first several months after the outbreak. Once investors price in the COVID-specific risks, the CDS spreads gradually decrease. In certain regions, such as Asia and the Pacific, governments are more effective in their efforts to control the spread of COVID-19. Therefore, we observe that their sovereign CDS spreads revert back to their normal levels at a faster speed.

\subsection{Methodology}

Our baseline model to examine the relationship between sovereign CDS spreads and COVID is as follows:

$$
\log \left(\operatorname{Spread}_{i, t}\right)=a_{0}+\beta_{1} \log \left(\operatorname{COVID}_{i, t}+1\right)+\gamma_{1} X_{i, t}+D_{t}+v_{i}+\varepsilon_{i, t},
$$

where $i$ is the country index, $t$ is the day index, COVID $_{i, t}$ is the number of daily new COVID-19 cases per million capita, Spread $_{i, t}$ is the five-year sovereign CDS spreads [5] and $\varepsilon_{i, t}$ is the error term. $v_{i}$ denotes country-fixed effects. $X_{i, t}$ is a set of risk factors. Prior studies have shown that sovereign credit risk is closely related to global factors (Favero et al., 2010; Gerlach et al., 2010; Longstaff et al., 2011; Galariotis et al., 2016). One important risk factor is the US stock market implied volatility (VIX), which can explain more than $30 \%$ of sovereign credit risk. Following these studies, we include US excess stock returns, treasury yields, corporate yield spreads, equity premiums, VIX index, US term spreads, VIX, regional sovereign CDS spreads and 
CFRI 11,3 global sovereign CDS spreads as our control variables [6]. $D_{t}$ is the weekday dummies controlling for possible seasonality of CDS spreads (Falagiarda and Gregori, 2015; Wang et al., 2021). All standard errors are clustered at the country and quarter levels to correct for potential cross-sectional and serial correlations in the error terms. Our coefficient of interest is $\beta_{1}$, which reflects the average effect of the pandemic on sovereign CDS spreads.

One potential identification concern pertains to omitted variables. We use state fixed effects to control for any time-invariant unobserved variables. For any time-varying omitted variables (e.g. increasingly widespread use of computer-based technologies), we include daily dummies in our regressions. Another identification issue is reverse causality. Firstly, there have been no studies that have shown that changes in CDS spreads might lead to an epidemic. Moreover, in our estimation, we test whether the COVID-19 risk at time $t-1$ would affect CDS spread at time $t$ (i.e. next day), which could further mitigate the reverse causality concern.

There are several studies showing that risky events could increase the volatility of financial markets and decrease the return of risky assets (Ulrich, 2012; Brogaard and Detzel, 2015; Wang et al., 2020). Moreover, Altig et al. (2020) show that COVID-19 creates great uncertainties and that more than half of the observed economic contractions are due to these COVID-induced uncertainties. Baker et al. (2020) show that the COVID-19 pandemic has increased stock market volatility at an unprecedented level. Since sovereign CDS spreads are indicators of country-level credit risk, we expect that they are positively related to the COVID19 pandemic.

\section{Empirical results}

In this section, we perform a detailed analysis of how the COVID-19 pandemic is impacting sovereign CDS spreads. First, we run multivariate regressions to examine the average effects of the pandemic on CDS spreads. Second, we perform two subsample analyses to investigate whether the effects of COVID-19 on CDS spreads varies across developed and developing economies. Then, we test whether the stringency of government policies in response to COVID-19 could drive the relationship between COVID-19 and CDS spreads. Lastly, we conduct several robustness checks in support of our main findings.

\subsection{Effects of COVID on sovereign CDS spreads}

Pan and Singleton (2008) and Longstaff et al. (2011) show that sovereign CDS spreads can be expressed as the compensation for the default-related risk premium and other risk premiums. Despite falling aggregate revenues, many economies have implemented costly fiscal stimulus plans to battle the pandemic. These policies significantly increase global debt. According to the Institute for International Finance, global debt reached a new record high of over $\$ 272 \mathrm{tn}$ in the third quarter of 2020 . For advanced economies, debt rose to over $432 \%$ of GDP in the third quarter, reflecting a 50 percentage points increase from 2019. For EMs, the debt level surged to over $248 \%$ of GDP. A result of this rising debt has been an increase in the default risk of these sovereign bonds. Additionally, the outbreak of COVID-19 substantially raises the level of economic uncertainty (Altig et al., 2020). Consequently, sovereign CDS investors demand a greater risk premium to compensate for the heightened uncertainty. Combining these two effects, we expect sovereign CDS spreads to be wider during periods when the pandemic is more severe.

Table 2 reports the estimation results of our baseline regressions. In column (1), the coefficient of COVID is 0.635 ( $t$-statistic $=4.788)$, which is statistically significant at the $1 \%$ level. This suggests that a $1 \%$ increase in the number of COVID-19 cases per 1,000 capita would lead to an average $0.635 \%$ increase in CDS spreads. We find a similar result after controlling for the country fixed effects, and daily dummies. For example, column (2) indicates that a $1 \%$ increase in COVID- 19 risk would lead to a $0.698 \%$ increase in a country's 


\begin{tabular}{|c|c|c|c|c|c|}
\hline & (1) & $(2)$ & (3) & (4) & Sovereign \\
\hline COVID & $0.635^{* * * *}(0.132)$ & $0.698^{* * * *}(0.090)$ & $0.698^{* * * *}(0.090)$ & $0.166^{* * * *}(0.055)$ & \\
\hline U.S. stock returns & & & & $0.038^{* * * *}(0.001)$ & \\
\hline Treasury yields & & & & $-0.239^{* * * *}(0.027)$ & \\
\hline Credit spread & & & & $0.131^{* * * *}(0.022)$ & \\
\hline Equity premium & & & & $-0.028^{* * * *}(0.006)$ & \\
\hline VIX & & & & $0.002^{* * *}(0.0009)$ & 293 \\
\hline Term spread & & & & $0.239 * * *(0.026)$ & \\
\hline Regional CDS spread & & & & $-0.0001(0.0000)$ & \\
\hline Global CDS spread & & & & $0.0005 * * *(0.0000)$ & \\
\hline Constant & $4.585^{* * * *}(0.015)$ & $4.639 * * *(0.177)$ & $4.592^{* * * *}(0.005)$ & $4.193^{* * * *}(0.058)$ & \\
\hline Country FE & No & Yes & Yes & Yes & \\
\hline Weekday dummies & No & No & Yes & Yes & \\
\hline $\operatorname{Adj} R^{2}$ & 0.003 & 0.053 & 0.053 & 0.506 & \\
\hline Observations & 10,718 & 10,718 & 10,718 & 10,718 & \\
\hline
\end{tabular}

Note(s): This table presents the regression results of the effect of COVID-19 on sovereign CDS spreads. We run the following regression: $\log \left(\operatorname{Spread}_{i, t}\right)=a_{0}+\beta_{1} \log \left(\mathrm{COVID}_{i, t}+1\right)+\gamma_{1} X_{i, t}+D_{t}+v_{i}+\varepsilon_{i, t}$, where $i$ is the country index, $t$ is the day index, COVID $i, t$ is the number of new COVID-19 cases per 1,000 capita, Spread $_{i, t}$ is the five-year sovereign CDS spread and $\varepsilon_{i, t}$ is the error term. $v_{i}$ denote country-fixed effect. $X_{i, t}$ is a set of risk factors. $D_{t}$ is the weekday dummies controlling for possible seasonality of CDS spreads. Variable definitions are provided in Table A2. Standard errors are clustered at the country and day levels and are reported in parentheses. The sample period is from January 2, 2020 to September 11,2020.*,** and *** indicate statistical significance at the 10,5 and $1 \%$ levels, respectively

Table 2. Baseline results

sovereign CDS spreads. In the last column, we control for various risk factors that have been shown to affect sovereign CDS spreads. We still observe that sovereign CDS spreads increase when the COVID-19 risk increases.

Overall, our results indicate that the widening of sovereign CDS spreads is caused by the COVID-19 pandemic. Our results are consistent with those of other recent studies that have examined the effect of COVID-19 on credit risk. For example, Agca et al. (2020) show that the CDS spreads of US firms with supply chain partners in China increase when this supply chain link was disrupted following the imposition of lockdown restrictions. Kartal (2020) finds that there has been an increase in the CDS spreads of Turkish firms during the COVID-19 pandemic. Kwan and Mertens (2020) estimate the effects of COVID-19 on corporate CDS spreads. Their results indicate a widening of CDS spreads in all sectors. Among investmentgrade firms, the energy sector has experienced the biggest widening. Cevik and Oztürkkal (2020) and Kartal (2020) find that CDS spreads have increased during the COVID-19 pandemic. Our paper differs from that of Daehler et al. (2020), who state that COVID-specific risk has not been a driving factor of EM sovereign CDS spreads during the pandemic and that, instead, traditional determinants such as fiscal space, oil shocks and monetary policies have been the main drivers.

\subsection{Subsample analyses}

3.2.1 Developed versus developing countries. Our sample covers sovereign CDS contracts for 26 developed and 52 developing countries. It makes sense to examine whether the effects of COVID-19 on CDS spreads vary across advanced and emerging economies. Compared with advanced economies, EMs have greater risk associated with their sovereign bonds. Consequently, investors demand a higher risk premium to compensate them for holding these bonds (Pouzo and Presno, 2016). This argument potentially explains why sovereign CDS spreads for EMs are higher than those for advanced economies. Additionally, developing countries typically have poorer financial and healthcare systems compared with developed 
CFRI 11,3

\section{4}

Table 3.

Subsample analysis: developed and developing countries countries. Thus, we should expect the impact of the pandemic on sovereign CDS spreads to be stronger in developing countries than in developed countries.

To investigate the above conjecture, we split our sample into developed and developing markets and then re-run our baseline regression in Eqn (1) for each subsample. We use the International Monetary Fund's (IMF) list of advanced and emerging economies. Table 3 presents our regression results for each subsample. We find that despite the fact that the coefficients of $\log \left(\mathrm{COVID}_{i, t}+1\right)$ are positive for both groups, nevertheless, they are significant only for developing economies. For example, for the IMF's classification of emerging and advanced economies, the coefficient on $\log \left(\operatorname{COVID}_{i, t}+1\right)$ is 0.136 and statistically significant for the developing subsample, while the coefficient becomes insignificant for the developed subsample.

As a robustness check, we also use the United Nations' Human Development Index (HDI) as another proxy variable. The HDI measures the level of human development in each country [7]. We classify a country as higher development if its HDI is above the median of the sample; otherwise we categorize it as a lower development country. We then perform a similar analysis based on this new classification. Our finding concerning the greater impact that COVID-19 has on developing economies' credit risk remains robust. This finding suggests that COVID-19 is as important as traditional credit risk factors in determining sovereign CDS spreads.

3.2.2 Healthcare system. To provide another interesting perspective, this time on the role of different countries' healthcare systems, we compare the impacts of COVID-19 on sovereign CDS spreads by splitting the sample into those countries with a higher level of healthcare and those with a lower level. We expect the results to show a greater impact from COVID-19 in countries with worse healthcare systems. Such a conjecture is straightforward because countries with better healthcare systems are better positioned to mitigate the risk of the pandemic.

We use two proxies for country's healthcare system. One is hospital beds per 1,000 people and another one is the number of special hospital beds per 1,000 people. We classify a country

\begin{tabular}{|c|c|c|c|c|}
\hline & \multicolumn{2}{|r|}{$\begin{array}{c}\text { Developed } \\
\text { (2) } \\
\text { Human development } \\
\text { index }\end{array}$} & $\begin{array}{c}\text { (3) } \\
\text { Dummy }\end{array}$ & $\begin{array}{l}\text { veloping } \\
\text { Human development } \\
\text { index }\end{array}$ \\
\hline COVID & $0.044(0.039)$ & $0.040(0.037)$ & 0.136 **** $(0.044)$ & $0.185 * * *(0.050)$ \\
\hline Controls & Yes & Yes & Yes & Yes \\
\hline Country FE & Yes & Yes & Yes & Yes \\
\hline $\begin{array}{l}\text { Weekday } \\
\text { dummies }\end{array}$ & Yes & Yes & Yes & Yes \\
\hline $\operatorname{Adj} R^{2}$ & 0.480 & 0.506 & 0.492 & 0.486 \\
\hline Observations & 3,670 & 5,414 & 7,048 & 5,163 \\
\hline
\end{tabular}

Note(s): This table investigates whether the effect of COVID-19 on CDS spreads varies across developed and less-developed economies. The dependent variable is the natural logarithm of five-years sovereign CDS spread. The other control variables are US excess stock return, treasury yields, corporate yield spreads, equity premium, VIX index, US term spread, VIX, regional sovereign CDS spreads, global sovereign CDS spreads and weekday dummies. Please see Table A2 for detailed descriptions of each variable. The IMF classification of developed and developing economies is reported in Table A1. Aside from the IMF classification, we also use the UN's Human Development Index to measure the level of development in each country, according to which a higher score indicates a higher level of development. Standard errors are clustered at the country and day levels and corrected for heteroskedasticity. The clustered standard errors are in parentheses. The sample period is from January 2, 2020 to September 11, 2020. *** and *** indicate statistical significance at the 10, 5 and 1\% levels, respectively 
as having a better healthcare system if its hospital beds per 1,000 people (or special hospital beds per 1,000 people) is above the median of our sample; otherwise, we classify it has having a worse healthcare system. We repeat our baseline regression in Eqn (1) for each group and report the regression results in Table 4 . The coefficient of COVID-19 is significantly positive in all specifications. However, we observe that the coefficient of COVID-19 is larger in the worse healthcare group (column (2)), which is more than twice the magnitude of that for the better healthcare group. This indicates that countries with better healthcare systems are in a better position to mitigate the effects of COVID-19 on sovereign CDS spreads. The results are robust if we use special beds per people as proxy for healthcare system. This piece of evidence is consistent with the results in Table 3 since developing economies typically have worse healthcare systems than developed economies.

\subsection{Role of government policies}

Nations around the world are taking action to battle the COVID-19 outbreak. Governments have imposed various coronavirus restrictions, such as the closure of schools and the imposition of restrictions on travel and socializing. Additionally, many countries have implemented economic policies such as income support and debt relief to overcome the adverse economic impact of the pandemic. However, the extent of government interventions and the strictness with which they are enforced varies across different countries. For example, China implemented strict two-month national lockdowns, quarantines and curfews in its attempt to rapidly and effectively control the spread of the disease. In contrast, the US'S response to the COVID-19 pandemic has been slow and loose. As a result, the US has suffered the largest outbreak in the world.

Bellas and Kosnik (2020) have documented the different ways in which different US states have responded to the pandemic. Some responded fairly rapidly in implementing stay-athome policies, while others reacted more slowly. Such differences in response are also evident at an international level. The University of Oxford has developed the Oxford COVID-19 Government Response Tracker (OxCGRT) to track the stringency of government policies in response to COVID-19 across more than 180 countries. Their stringency measure is based on eight indicators, such as school closures and restrictions in movement, and this offers us an

\begin{tabular}{lcccc}
\hline & \multicolumn{2}{c}{ Overall hospital beds } & \multicolumn{2}{c}{ Special hospital beds } \\
& Better healthcare & Worse healthcare & Better healthcare & Worse healthcare \\
& $(1)$ & $(2)$ & $(3)$ & $0.108^{* * *}(0.037)$ \\
\hline COVID & $0.085^{* *}(0.039)$ & $0.234^{* * * *}(0.043)$ & Yes & $0.190^{* * * *}(0.050)$ \\
Controls & Yes & Yes & Yes & Yes \\
Country FE & Yes & Yes & Yes & Yes \\
Weekday dummies & Yes & Yes & 0.561 & 0.476 \\
Adj $R^{2}$ & 0.506 & 0.496 & 5,440 & 5,278 \\
Observations & 5,296 & 5,140 &
\end{tabular}

Note(s): This table investigates whether the effect of COVID-19 on CDS spreads varies across developed and less-developed economies. The dependent variable is the natural logarithm of five-years sovereign CDS spread. The other control variables are US excess stock return, treasury yields, corporate yield spreads, equity premium, VIX index, US term spread, VIX, regional sovereign CDS spreads, global sovereign CDS spreads and weekday dummies. Please see Table A2 for detailed descriptions of each variable. We use the number of hospital beds (or special beds) per 1,000 people to measure the level of healthcare infrastructure for each country, with higher values indicating more established healthcare systems. Standard errors are clustered at the country and day levels and corrected for heteroskedasticity. The clustered standard errors are in parentheses. The sample period is from January 2,2020 to September 11,2020. *,** and *** indicate statistical significance at the 10,5 and $1 \%$ levels, respectively
Sovereign credit risk

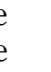


CFRI 11,3

\section{6}

opportunity to test for the heterogenous effects resulting from lockdown policies. Based on data from OxCGRT, we can investigate the role of government policies in driving the CDSCOVID-19 relationship.

The results are reported in Table 5. We find that the effect of the pandemic on sovereign CDS spreads is significantly positive for both subsamples. The coefficient of COVID is 0.178 for countries that have enacted stricter government policies in response to the pandemic, while the coefficient is 0.149 for countries with less strict policies. These results suggest that the effect of the pandemic on sovereign CDS spreads is stronger for countries that implement stricter government policies.

\subsection{Robustness checks}

In this subsection, we conduct additional robustness analysis to support our main finding: that COVID-19 increases sovereign CDS spreads. Our first concern is the fact that the COVID19 pandemic has worsened during certain periods and in certain countries and therefore our results could be driven by those outliers. To mitigate this concern, we winsorize all variables at the $1 \%$ level, and we subsequently use these winsorized variables to re-estimate the baseline regressions. The results in columns (1) in of Table 6 show that the positive relationship between CDS spreads and COVID-19 remains significant at the 1\% level. Another approach to address this concern is to remove the countries in our sample that have suffered from particularly severe COVID-19 outbreaks. Based on the statistics of the Johns Hopkins Coronavirus Resource Center, the United States, Brazil and India are the top three countries with the greatest number of confirmed cases. Thus, we remove those three countries and re-estimate our regression model. The result summarized in column (2) still show strong positive correlation between COVID-19 and sovereign CDS spreads.

Next, we show that our results hold once we use other COVID-19 indicators. We use the following proxy variables for the COVID-19 pandemic as one of our robustness checks: the changes in daily death numbers per million capita, and the number of new confirmed cases. The columns (3) and (4) of Table 6 show that CDS spreads widen when the COVID-19 pandemic is more severe at the $1 \%$ significance level.

Lastly, in the main analysis, we clustered the standard errors at both day and country levels. However, to verify the robustness of our main results, we cluster the errors at the country or day levels alone. In the last two columns of Table 6, we report the estimation

\begin{tabular}{lcc}
\hline & $(1)$ & $(2)$ \\
& More & Less \\
\hline COVID & $0.178^{* * * *}(0.046)$ & $0.149^{* * *}(0.040)$ \\
Controls & Yes & Yes \\
Country FE & Yes & Yes \\
Weekday dummies & Yes & Yes \\
Adj $R^{2}$ & 0.514 & 0.512 \\
Observations & 5,396 & 5,243
\end{tabular}

Note(s): This table focuses on the effect of government policy on driving the CDS spread-COVID-19 relationship. The dependent variable is the natural logarithm of five-years sovereign CDS spread. The other control variables are US excess stock return, treasury yields, corporate yield spreads, equity premium, VIX index, US term spread, VIX, regional sovereign CDS spreads, global sovereign CDS spreads and weekday dummies. The level of stringency of government policy in response to COVID-19 is obtained using data from the Oxford COVID-19 Government Response Tracker (OxCGRT). Higher values on the OxCGRT index indicate more stringent policy responses. Please see Table A2 for detailed descriptions of each variable. Standard errors

Table 5. are clustered at the country and day levels and corrected for heteroskedasticity. The clustered standard errors The role of government are in parentheses. The sample period is from January 2, 2020 to September 11, 2020.*,** and *** indicate policy 


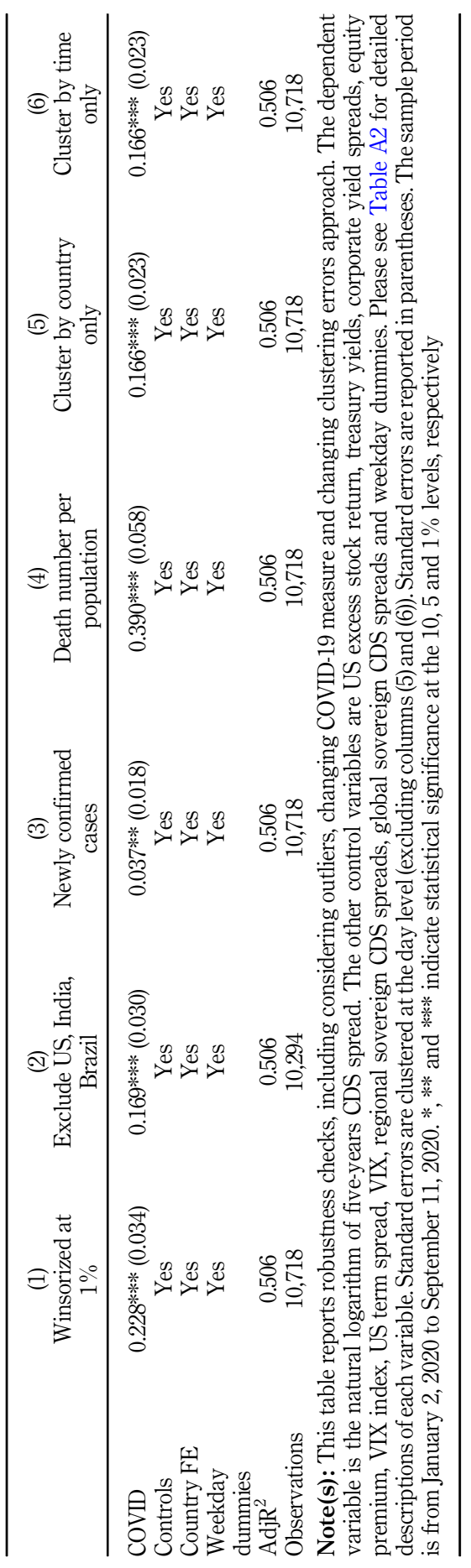

Sovereign credit risk

Table 6. Robustness checks 
CFRI 11,3 results. It is clear that the coefficients of COVID that we previously observed to have significant effect remain statistically significant.

\section{Conclusion}

In this paper, we study whether and how the COVID-19 pandemic affects sovereign credit risk using an extensive cross-section of CDS contract data on the external debt of 78 developed and developing countries. We find that the level of sovereign CDS spreads increases during periods when the COVID-19 pandemic becomes more severe. Our results are robust after controlling for important risk factors as well as country-fixed effects. Furthermore, the effects of COVID-19 on CDS spreads are stronger in developing countries and countries with worse healthcare infrastructures. The policies adopted by governments in response to COVID-19 do not significantly reduce the effect on CDS spreads. In summary, our results suggest that COVID-19 is an important source of variation in sovereign CDS spreads.

\section{Notes}

1. https://covid19.who.int/ (accessed October 1, 2020).

2. https://www.eiu.com/n/covid-19-to-send-almost-all-g20-countries-into-a-recession/

3. Interested readers may refer to Covid Economics, published by the Centre for Economic Policy Research, for relevant studies (https://cepr.org/content/covid-economics-vetted-and-real-timepapers-0).

4. For example, on March 27, 2020, the US congress passed the Coronavirus Aid, Relief and Economic Security Act, which is a $\$ 2.2 \mathrm{tn}$ economic stimulus bill. The European Union introduced a $\$ 857 \mathrm{bn}$ recovery plan on July $21,2020$.

5. The distribution of COVID-19 and CDS spread contain many outliers, so we take logarithm to mitigate the effect of outliers.

6. The definitions and data sources of these variables are reported in Table A2.

7. http://hdr.undp.org/en/content/human-development-index-hdi

\section{References}

Adekoya, O.B. and Oliyide, J.A. (2020), "How COVID-19 drives connectedness among commodity and financial markets: evidence from TVP-VAR and causality-in-quantiles techniques", Resources Policy, Vol. 70, 101898.

Agca, S., Birge, J.R., Wang, Z.A. and Wu, J. (2020), "The impact of COVID-19 on supply chain credit risk", SSRN 3639735.

Altig, D., Baker, S., Barrero, J.M., Bloom, N., Bunn, P., Chen, S., Davis, S.J., Leather, J., Meyer, B. and Mihaylov, E. (2020), "Economic uncertainty before and during the COVID-19 pandemic", Journal of Public Economics, Vol. 191, 104274.

Baker, S.R., Bloom, N., Davis, S.J., Kost, K., Sammon, M. and Viratyosin, T. (2020), "The unprecedented stock market reaction to COVID-19", The Review of Asset Pricing Studies, Vol. 10 No. 4, pp. $742-758$.

Berg, A. and Sachs, J. (1988), "The debt crisis: structural explanations of country performance", Journal of Development Economics, Vol. 29 No. 3, pp. 271-306.

Blanco, R., Brennan, S. and Marsh, I.W. (2005), "An empirical analysis of the dynamic relation between investment-grade bonds and credit default swaps", Journal of Finance, Vol. 60 No. 5, pp. 2255-2281.

Brogaard, J. and Detzel, A. (2015), "The asset-pricing implications of government economic policy uncertainty", Management Science, Vol. 61 No. 1, pp. 3-18. 
Bulow, J. and Rogoff, K. (1989), "Sovereign debt: is to forgive to forget?", American Economic Review, Vol. 79 No. 1, pp. 43-50.

Cevik, S. and Öztürkkal, B. (2020), "Contagion of fear: is the impact of COVID-19 on sovereign risk really indiscriminate? No. 2020/263", International Monetary Fund.

Daehler, T., Aizenman, J. and Jinjarak, Y. (2020), Emerging Markets Sovereign Spreads and Countryspecific Fundamentals during COVID-19 (No. W27903), National Bureau of Economic Research, Cambridge, MA.

Falagiarda, M. and Gregori, W.D. (2015), "The impact of fiscal policy announcements by the Italian government on the sovereign spread: a comparative analysis", European Journal of Political Economy, Vol. 39, pp. 288-304.

Falato, A., Goldstein, I. and Hortaçsu, A. (2020), "Financial fragility in the COVID-19 crisis: the case of investment funds in corporate bond markets", NBER Working Paper, (w27559).

Favero, C., Pagano, M. and Von Thadden, E.L. (2010), "How does liquidity affect government bond yields?", Journal of Financial and Quantitative Analysis, Vol. 45, pp. 107-134.

Galariotis, E.C., Makrichoriti, P. and Spyrou, S. (2016), "Sovereign CDS spread determinants and spillover effects during financial crisis: a panel VAR approach", Journal of Financial Stability, Vol. 26, pp. 62-77.

Gerlach, S., Schulz, A. and Wolff, G.B. (2010), Banking and Sovereign Risk in the Euro Area, Deutsche Bundesbank Discussion Paper.

Gilchrist, S. and Zakrajsek, E. (2012), "Credit spreads and business cycle fluctuations”, American Economic Review, Vol. 102 No. 4, pp. 1692-1720.

Goodell, J.W. (2020), “COVID-19 and finance: agendas for future research", Finance Research Letters, 101512 .

Grossman, H.I. and Van Huyck, J.B. (1988), "Sovereign debt as a contingent claim: excusable default, repudiation, and reputation”, American Economic Review, Vol. 78 No. 5, pp. 1088-1097.

Gündüz, Y. and Kaya, O. (2014), "Impacts of the financial crisis on eurozone sovereign CDS spreads", Journal of International Money and Finance, Vol. 49, pp. 425-442.

Kartal, M.T. (2020), "The behavior of Sovereign credit default swaps (CDS) spread: evidence from Turkey with the effect of Covid-19 pandemic", SSRN 3642652.

Kwan, S.H. and Mertens, T.M. (2020), "Market assessment of COVID-19", FRBSF Economic Letter, Vol. 2020 No. 14, pp. 1-5.

Longstaff, F.A., Mithal, S. and Neis, E. (2005), "Corporate yield spreads: default risk or liquidity? New evidence from the credit default swap market", Journal of Finance, Vol. 60 No. 5, pp. 2213-2253.

Longstaff, F.A., Pan, J., Pedersen, L.H. and Singleton, K.J. (2011), "How sovereign is sovereign credit risk?", American Economic Journal: Macroeconomics, Vol. 3 No. 2, pp. 75-103.

Mazur, M., Dang, M. and Vega, M. (2020), "COVID-19 and the march 2020 stock market crash. Evidence from S\&P1500", Finance Research Letters, Vol. 38, 101690.

McKibbin, W.J. and Fernando, R. (2020), The Global Macroeconomic Impacts of COVID-19: Seven Scenarios.

Njindan Iyke, B. (2020), "The disease outbreak channel of exchange rate return predictability: evidence from COVID-19”, Emerging Markets Finance and Trade, Vol. 56 No. 10, pp. 2277-2297.

Pan, J. and Singleton, K.J. (2008), "Default and recovery implicit in the term structure of sovereign CDS spreads", The Journal of Finance, Vol. 63 No. 5, pp. 2345-2384.

Pouzo, D. and Presno, I. (2016), "Sovereign default risk and uncertainty premia”, American Economic Journal: Macroeconomics, Vol. 8, pp. 230-66.

Reinders, H.J., Schoenmaker, D. and Van Dijk, M.A. (2020), "Is COVID-19 a threat to financial stability in Europe?”, Working paper. 
CFRI 11,3

300
Remolona, E.M., Scatigna, M. and Wu, E. (2008), "The dynamic pricing of sovereign risk in emerging markets: fundamentals and risk aversion", The Journal of Fixed Income, Vol. 17 No. 4, pp. 57-71.

Ulrich, M. (2012), "Economic policy uncertainty and asset price volatility", SSRN 1566909.

Wang, X., Xu, W. and Zhong, Z. (2019), "Economic policy uncertainty, CDS spreads, and CDS liquidity provision", Journal of Futures Markets, Vol. 39, pp. 461-480.

Wang, X., Wu, Y. and Xu, W. (2020), “Geopolitical risk and investment”, Working paper. doi: 10.2139/ ssrn.3305739.

Wang, X., Xu, W. and Zhong, Z. (2021), "Temporal effects in index CDS trading and liquidity", Working paper. doi: 10.2139/ssrn.3607660.

Yu, F. (2002), "Modeling expected return on defaultable bonds", Journal of Fixed Income, Vol. 12 No. 2, pp. 69-81.

\section{Appendix 1}

\begin{tabular}{lllll}
\hline Developed & & Developing & & \\
\hline Austria & Latvia & Algeria & Ghana & Philippines \\
Australia & Lithuania & Angola & Guatemala & Poland \\
Belgium & Netherlands & Argentina & India & Qatar \\
Canada & Norway & Brazil & Indonesia & Romania \\
Germany & New Zealand & Bulgaria & Iraq & Russia \\
Denmark & Portugal & Cameroon & Jamaica & Saudi Arabia \\
Finland & Slovenia & Chile & Jordan & Senegal \\
France & Spain & China & Kazakhstan & South Africa \\
Greece & Sweden & Colombia & Kenya & Sri Lanka \\
Ireland & Switzerland & Costa Rica & Kuwait & Thailand \\
Israel & United Kingdom & Côte d'Ivoire & Malaysia & Turkey \\
Italy & United States & Croatia & Mexico & Ukraine \\
Japan & & Dominican Republic & Morocco & United Arab Emirates \\
Korea & & Ecuador & Nigeria & Uruguay \\
& & Egypt & Oman & Vietnam \\
& & El Salvador & Pakistan & Zambia \\
& & Ethiopia & Panama & \\
& & Georgia & Peru &
\end{tabular}

Table A1.

Note(s): This classification is based on the IMF's World Economic Outlook database April 2017 (http://www. imf.org/external/pubs/ft/weo/2017/01/weodata/weoselgr.aspx) 
Appendix 2

\begin{tabular}{|c|c|c|c|}
\hline Variables & Definition & Source & \\
\hline COVID & $\begin{array}{l}\text { The number of daily new COVID-19 cases } \\
\text { per million capita }\end{array}$ & $\begin{array}{l}\text { Our World in Data } \\
\text { https://ourworldindata.org/coronavirus }\end{array}$ & \\
\hline Spread & Five-year sovereign CDS spread & Markit Group Limited & 301 \\
\hline US stock returns & $\begin{array}{l}\text { The US stock market excess return is the } \\
\text { value-weighted return on all NYSE, AMEX } \\
\text { and NASDAQ stocks minus the three- } \\
\text { month Treasury-bill return }\end{array}$ & $\begin{array}{l}\text { Kenneth French website } \\
\text { https://mba.tuck.dartmouth.edu/pages/ } \\
\text { faculty/ken.french/data_library.html }\end{array}$ & \\
\hline Treasury yields & $\begin{array}{l}\text { Treasury yields are based on the five-year } \\
\text { constant maturity Treasury }\end{array}$ & Fred St Louis & \\
\hline Credit spread & $\begin{array}{l}\text { The basis-point yield spread between BBB } \\
\text { and AAA bonds }\end{array}$ & Fred St Louis & \\
\hline Term spread & $\begin{array}{l}\text { The difference between } 10 \text {-years US } \\
\text { government bond rate and 3-months US } \\
\text { government bond rate }\end{array}$ & Fred St Louis & \\
\hline Equity premium & $\begin{array}{l}\text { Daily changes in the price-earnings ratio for } \\
\text { the S\&P } 500 \text { index }\end{array}$ & $\begin{array}{l}\text { http://www.econ.yale.edu/ shiller/data. } \\
\text { htm }\end{array}$ & \\
\hline VIX & $\begin{array}{l}\text { CBOE Volatility Index, measuring } \\
\text { estimated volatility for the S\&P } 500\end{array}$ & Fred St Louis & \\
\hline $\begin{array}{l}\text { Regional CDS } \\
\text { spread }\end{array}$ & $\begin{array}{l}\text { For each country, we compute the regional } \\
\text { CDS spread by taking the average of the } \\
\text { CDS spreads for all of the other countries in } \\
\text { that country's region }\end{array}$ & Author calculation & \\
\hline Global CDS spread & $\begin{array}{l}\text { For each country, we also compute the } \\
\text { global CDS spread by taking the average of } \\
\text { the CDS spreads for all the countries outside } \\
\text { that country's region }\end{array}$ & Author calculation & \\
\hline Human & A summary measure of average & Our World in Data & \\
\hline $\begin{array}{l}\text { Development Index } \\
\text { (HDI) }\end{array}$ & $\begin{array}{l}\text { achievement in key dimensions of human } \\
\text { development }\end{array}$ & https://ourworldindata.org/coronavirus & \\
\hline Hospital beds & Beds per 1,000 people & $\begin{array}{l}\text { Our World in Data } \\
\text { https://ourworldindata.org/coronavirus }\end{array}$ & \\
\hline $\begin{array}{l}\text { Hospital special } \\
\text { beds }\end{array}$ & Special beds per 1,000 people & $\begin{array}{l}\text { WHO } \\
\text { https:/gateway.euro.who.int/en/ } \\
\text { search/?q=hospital } \% 20 \text { beds } \% \\
\text { 20statistics }\end{array}$ & \\
\hline Stringency & $\begin{array}{l}\text { The Oxford COVID-19 Government } \\
\text { Response Tracker that systematically } \\
\text { collects information on several different } \\
\text { common policy responses that } \\
\text { governments have taken to respond to the } \\
\text { pandemic on } 18 \text { indicators, such as school } \\
\text { closures and travel restrictions }\end{array}$ & $\begin{array}{l}\text { https://www.bsg.ox.ac.uk/research/ } \\
\text { research-projects/coronavirus- } \\
\text { government-response-tracker }\end{array}$ & $\begin{array}{r}\text { Table A2. } \\
\text { Variable definitions } \\
\text { and data sources }\end{array}$ \\
\hline
\end{tabular}

Corresponding author

Xinjie Wang can be contacted at: xinjie.wang@sustech.edu.cn

For instructions on how to order reprints of this article, please visit our website:

www.emeraldgrouppublishing.com/licensing/reprints.htm

Or contact us for further details: permissions@emeraldinsight.com 